\title{
Methanesulphonate utilization by a novel methylotrophic bacterium involves an unusual monooxygenase
}

\author{
Don P. Kelly, ${ }^{1}$ Simon C. Baker,${ }^{2} \dagger$ Jim Trickett,$\ddagger$ Margaret Davey $^{2}$ \\ and J. Colin Murrell ${ }^{2}$
}

Author for correspondence: J. Colin Murrell. Tel: +44 203 523553. Fax: +44203523568.

Departments of Science Education ${ }^{1}$ and Biological Sciences ${ }^{2}$, University of Warwick, Coventry CV4 7AL, UK

\begin{abstract}
Methylotroph strain M2, isolated from soil, was capable of growth on methanesulphonic acid (MSA) as sole carbon and energy source. MSA was oxidized by cell suspensions with an MSA: oxygen stoichiometry of 1.0:2.0, indicating complete conversion to carbon dioxide and sulphate. The presence of formaldehyde and formate dehydrogenases and hydroxypyruvate reductase in MSA-grown bacteria indicated the production of formaldehyde from MSA (and its further oxidation for energy generation), and assimilation of formaldehyde by means of the serine pathway. Growth yields in MSA-limited chemostat culture were a function of dilution rate, with yield ranging from $7.0 \mathrm{~g} \mathrm{~mol}^{-1}$ at $D=0.04 \mathrm{~h}^{-1}$, to 14.6 at $0.09 \mathrm{~h}^{-1}$. MSA metabolism was not initiated by hydrolysis to produce either methane or methanol, but appears to be by an NADH-dependent methanesulphonate monooxygenase, cleaving MSA into formaldehyde and sulphite. The organism lacked ribulose bisphosphate carboxylase and did not fix carbon dioxide autotrophically. It also lacked ribulose-monophosphate-dependent hexulose phosphate synthase. Growth on methanol, methylammonium and other $C_{1}$ compounds was exhibited, but ability to oxidize MSA was not induced by growth on these substrates. Similarly, methylammonium (MMA) was only oxidized by strain M2 grown on MMA. Growth on methanol involved a pyrroloquinoline quinone (PQQ)-linked methanol dehydrogenase (large subunit molecular mass $60 \mathrm{kDa}$ ). This organism is the first methylotroph shown to have the ability to oxidize MSA, by virtue of a novel monooxygenase, and is significant in the global sulphur cycle as MSA can be a major product of the oxidation in the atmosphere of dimethyl sulphide, the principal biogeochemical sulphur gas.
\end{abstract}

Keywords: methylotrophy, methanesulphonic acid (MSA), MSA oxygenase, $\mathrm{C}_{1}$ metabolism, alkyl sulphonates

\section{INTRODUCTION}

The principal organic sulphur compound entering the atmosphere from terrestrial and aquatic environments is dimethyl sulphide (DMS): this arises from marine algae, cyanobacteria, marsh plants such as Spartina and lesser

†Present address: Department of Biochemistry, University of Oxford, Oxford OX1 3QU, UK.

$\ddagger$ Deceased (12th April 1993).

Abbreviations: $C T A B$, cetyl trimethylammonium bromide; DMS, dimethyl sulphide; $M D H$, methanol dehydrogenase; MSA, methanesulphonic acid; MSMO, methanesulphonate monooxygenase; PQQ, pyrroloquinoline quinone; RubisCO, ribulose 1,5-bisphosphate carboxylase/oxygenase. terrestrial sources (Andreae, 1986; Kelly \& Smith, 1990; Watts et al., 1990; Dacey et al., 1987; de Zwart \& Kuenen, 1992). There is now good evidence that DMS in sea water is primarily derived from the degradation of dimethylsulphonium propionate, an osmolyte produced by many algal species and marine plants (Kiene, 1993). Annual global production of DMS into the atmosphere has been estimated to be of the order of $45 \mathrm{Tg}$ sulphur, representing a significant fraction of the global biogeochemical sulphur cycle, but one whose subsequent fate in the cycle is only partly understood (Kelly \& Smith, 1990).

A major product of the photochemical destruction of DMS in the atmosphere is methanesulphonic acid 
$\left(\mathrm{CH}_{3} \mathrm{SO}_{3} \mathrm{H} ; \mathrm{MSA}\right)$, with sulphur dioxide and lesser quantities of other sulphur compounds also being generated (Grosjean \& Lewis, 1982; Hatakeyama et al., 1982; Ferek et al., 1986). DMS is also oxidized to MSA by atmospheric $\mathrm{NO}_{3}$ radicals in the dark (i.e. night time) and photochemically with $\mathrm{NO}_{\mathbf{x}}$ (Yin et al., 1990; Jensen et al., 1991, 1992; Berresheim et al., 1990). The reactions involved have been summarized by Kelly et al. (1993). MSA is a strong stable acid that does not undergo photochemical breakdown and is consequently deposited on the Earth's surface in rain and snow, thus re-entering both the terrestrial and aquatic biosphere. Evidence of continuous global deposition of MSA over many thousands of years has come from examination of MSA concentrations at different depths in Antarctic ice (Saigne \& Legrand, 1987). The subsequent fate of MSA in the biosphere is not fully understood at present and there is little in the literature on the biodegradation of MSA. MSA was used as a sulphur source by Chlorella fusca but was the least well used of the $\mathrm{C}_{1}-\mathrm{C}_{8}$ alkyl sulphonates tested (Biedlingmaier \& Schmidt, 1983; Krauss \& Schmidt, 1987). MSA has also been identified as a sulphur source for bacteria isolated from soil and sewage (Cook \& Hütter, 1982) and certain enteric bacteria (Uria-Nickelsen et al., 1993).

We previously described the isolation from soil of a novel Gram-negative methylotrophic bacterium, strain M2, that utilizes MSA as a sole source of carbon and energy (Baker et al., 1991). We report here on the characterization of this bacterium and on the mechanism of MSA metabolism. Our experimental approach was based on the hypothesis that the initial step in MSA breakdown would be one of: (i) hydrolysis to yield methane; (ii) hydrolysis to methanol and sulphite, (iii) conversion to methyltetrahydrofolate and sulphate; or (iv) $\mathrm{NAD}(\mathrm{P}) \mathrm{H}$-specific attack by an MSA-specific monooxygenase to produce formaldehyde and sulphite. We present evidence for the last of these.

\section{METHODS}

Organism and growth conditions. Methylotroph strain M2 (Baker et al., 1991) was maintained on agar slants containing $15 \mathrm{mM}$ MSA in a mineral salts medium (Min E) based on that of Owens \& Keddie (1969) containing, per litre of distilled water: $1.2 \mathrm{~g} \mathrm{~K}_{2} \mathrm{HPO}_{4} ; 0.624 \mathrm{~g} \mathrm{KH}_{2} \mathrm{PO}_{4} ; 0.05 \mathrm{~g} \mathrm{CaCl}_{2} .6 \mathrm{H}_{2} \mathrm{O} ; 0.165 \mathrm{~g}$ $\mathrm{MgCl}_{2} .6 \mathrm{H}_{2} \mathrm{O} ; 0.5 \mathrm{~g} \mathrm{NH} \mathrm{Nl}_{4} ; 2 \mathrm{ml}$ trace elements solution (Tuovinen \& Kelly, 1973). Phosphates were autoclaved separately. Where necessary, $\mathrm{MgCl}_{2} \cdot 6 \mathrm{H}_{2} \mathrm{O}$ replaced $\mathrm{MgSO}_{4} \cdot 7 \mathrm{H}_{2} \mathrm{O}$ for an essentially sulphate-free medium ( $\mathrm{Min} \mathrm{E}-\mathrm{S}$ ). For comparative growth experiments, carbon substrates were routinely added as filter-sterilized solutions to yield a final concentration of $15 \mathrm{mM}$, unless otherwise stated. Batch cultures of strain M2 were routinely grown in fermenters to provide biomass for enzyme assays and oxygen electrode experiments. These were either $1000 \mathrm{ml} \mathrm{LH} 100$ series or $5000 \mathrm{ml} \mathrm{LH} 210$ series vessels equipped with $\mathrm{pH}$, oxygen and temperature control. A constant temperature of $30^{\circ} \mathrm{C}$ and $\mathrm{pH} 6.8$ were used throughout and air was supplied to fermenters at $1 \mathrm{ml}(\mathrm{ml}$ culture $)^{-1} \mathrm{~min}^{-1}$. The purity of cultures was checked microscopically and by plating out dilutions of strain M2 on to nutrient agar, MSA agar and formate agar. Criteria for purity included uniformity of colony morphology on MSA agar and formate agar and absence of growth on nutrient agar. Cell dry weight estimates were by the method of Gerhardt (1981). Chemostat cultures were established in 750 or $1000 \mathrm{ml}$ waterjacketed vessels, with conditions maintained as above. Medium was pumped into the cultures using Watson Marlow flow inducers, and biomass production measured at several dilution rates.

Analytical methods. Formate in culture supernatants was determined by the method of Lang \& Lang (1972). The concentration of formaldehyde in culture supernatants and in solutions prepared from paraformaldehyde was determined by the method developed by Nash (1953). Methanol in culture supernatants was assayed by gas chromatography using a Pye Unicam series 204 gas chromatograph fitted with a flame ionization detector, and a Poropak Q column $(1.5 \mathrm{~m} \times 2.3 \mathrm{~mm})$ operated isothermally at $160^{\circ} \mathrm{C} . \mathrm{N}_{2}$ was used as carrier gas at $30 \mathrm{ml} \mathrm{min}{ }^{-1}$. Sulphite was detected qualitatively using Ellman's reagent (Johnston et al., 1975). Sulphate was determined by precipitation with an excess of barium ions (in $1 \%, v / v, \mathrm{HCl}$ ) and measurement of residual barium by atomic absorption spectrophotometry at $553.6 \mathrm{~nm}$, using potassium hydrogen sulphate as a standard. SDS-PAGE analysis of cell-free extracts was carried out on $12 \%(\mathrm{w} / \mathrm{v}$ ) acrylamide gels (Laemmli, 1970). The Western blotting procedure (Towbin et al., 1979) was carried out using a Gradipore electroblotting system and Hybond $\mathrm{C}$ nitrocellulose (Amersham). Antibody to the large subunit of methanol dehydrogenase from Metbylobacterium extorquens AM1, was kindly supplied by Professor C. Anthony. Total chromosomal DNA from strain M2 was purified by the method of Oakley \& Murrell (1988). Determination of the mol \% G $+C$ of the DNA of strain $M$ was by the spectrophotometric method of Fredericq et al. (1961). Escherichia coli DNA was used as a control for this method. Southern blotting, nick translation, hybridization methods and routine DNA handling techniques were by the methods of Maniatis et al. (1982).

Whole-cell oxygen electrode studies. Cells were harvested by centrifugation at $10000 \mathrm{~g}$ for $10 \mathrm{~min}$ at $4{ }^{\circ} \mathrm{C}$. Resultant cell pellets were washed in $25 \mathrm{mM}$ Tris $/ \mathrm{HCl}, \mathrm{pH} 7 \cdot 0(100 \times$ pellet volume $)$ and then centrifuged at $10000 \mathrm{~g}\left(10 \mathrm{~min}\right.$ at $\left.4{ }^{\circ} \mathrm{C}\right)$. This was repeated several times. Cells were resuspended in the same buffer and either drop-frozen in liquid nitrogen prior to storage at $-70^{\circ} \mathrm{C}$ or kept on ice for immediate use. Oxygen uptake by whole cells was measured using a Clark-type oxygen electrode. Assays were carried out at $30^{\circ} \mathrm{C}$ in a total volume of $3 \mathrm{ml}$ $40 \mathrm{mM}$ Tris $/ \mathrm{HCl}, \mathrm{pH} 7 \cdot 0$, with $30-50 \mathrm{mg}$ dry wt of washed cells. After measuring the endogenous oxygen consumption rate for at least $2 \mathrm{~min}, 1.7 \mathrm{mM}$ substrate was added and subsequent rate of oxygen consumption measured. Values reported are means of at least four independent assays. Apparent $K_{\mathrm{m}}$ values for MSA and other $\mathrm{C}_{1}$ substrates were determined using substrate concentration ranges of 0.02-1.0 mM.

Enzyme assays. These were performed at $30^{\circ} \mathrm{C}$ using cell-free extracts of chemostat-grown cells. Organisms were harvested by centrifugation from chemostats maintained at a dilution rate of $80 \%$ of $\mu_{\max }$ for the particular carbon and energy source used, and broken by one passage through a chilled French pressure cell at $137 \mathrm{MPa}$. Cell debris was removed by centrifugation at $50000 \mathrm{~g}\left(75 \mathrm{~min}\right.$ at $\left.4{ }^{\circ} \mathrm{C}\right)$ to yield a cell-free extract which was used immediately or drop-frozen in liquid nitrogen and stored at $-70^{\circ} \mathrm{C}$. Protein content was determined using the method of Bradford (1976). Hydroxypyruvate reductase and hexulose phosphate synthase were assayed by the method of Kelly \& Wood (1984). Ribulose 1,5-bisphosphate carboxylase/ oxygenase (RubisCO) was assayed for in cells permeabilized using cetyl trimethylammonium bromide (CTAB) or Triton X100 (Leadbeater et al., 1982; Wood \& Kelly, 1989). Methanol 
dehydrogenase and formate dehydrogenase were assayed by the methods of Day \& Anthony (1990) and Jollie \& Lipscombe (1990), respectively. MSA oxygenase activity was determined spectrophotometrically by following the substrate-stimulated oxidation of NADH at $340 \mathrm{~nm}$. Reaction mixtures contained (in a total volume of $1 \mathrm{ml}): 20 \mu \mathrm{mol}$ Tris $/ \mathrm{HCl}, \mathrm{pH} 7 \cdot 0 ; 0.4 \mu \mathrm{mol}$ $\mathrm{NADH}, 0.5 \mu \mathrm{mol} \mathrm{MSA}$ and sufficient protein to give a linear rate of $\mathrm{NADH}$ oxidation for $2-3 \mathrm{~min}(0.2-0.5 \mathrm{mg}$ protein). All enzyme activities reported are the mean of at least three separate determinations.

Special chemicals and materials. $\left[{ }^{14} \mathrm{C}\right] \mathrm{MSA}$ was kindly provided by Dr J. E. Bakke (USDA, ARS Biosciences Research Laboratory, Fargo, ND, USA). We are grateful to Professor C. Anthony and Dr F. R. Tabita for gifts of antibodies to the large subunit of methanol dehydrogenase and RubisCO, respectively. $\left[{ }^{14} \mathrm{C}\right]$ Carbonate was from Amersham and all other chemicals were AnalaR or similar grades from Aldrich, Sigma and Fisons (UK).

\section{RESULTS}

\section{DNA base composition and growth substrates used by strain $M 2$}

DNA from strain M2 contained $61 \mathrm{~mol} \% \mathrm{G}+\mathrm{C}$. Attempts to characterize the organism using the standard API $20 \mathrm{E}$ system were unsuccessful as the organism gave negative results in 28 of 32 tests. This was due in part to its failure to grow on rich organic media such as nutrient agar. Growth on glucose or fructose was not accompanied by acid production. Strain M2 gave positive assays for urease and catalase and grew at 30 and $37^{\circ} \mathrm{C}$ but not at $45^{\circ} \mathrm{C}$. The organism was a highly motile Gram-negative rod, $2-4 \mu \mathrm{m} \times 1 \mu \mathrm{m}$, occurring as single cells or as pairs of cells during growth on MSA. Optimum temperature was $30^{\circ} \mathrm{C}$ and optimum $\mathrm{pH} 6.6$.

\section{Growth substrate spectrum of strain M2}

Strain M2 was tested for aerobic growth in batch culture on a range of methylotrophic and heterotrophic carbon sources. Specific growth rates and apparent growth yield

Table 1. Growth substrates for strain M2

\begin{tabular}{|lcc|}
\hline Substrate (15 mM) & $\begin{array}{c}\text { Specific } \\
\text { growth rate } \\
\mathbf{( h}^{-\mathbf{1}} \mathbf{)}\end{array}$ & $\begin{array}{c}\text { Observed } \\
\text { growth yield } \\
\text { (g dry wt } \mathbf{~ m o l}^{-\mathbf{1}} \text { ) }\end{array}$ \\
\hline MSA & $0 \cdot 10$ & $8 \cdot 0-14 \cdot 2$ \\
Amino-MSA & ND & $7 \cdot 4$ \\
Methanol & $0 \cdot 14$ & $12 \cdot 6$ \\
Methylammonium & $0 \cdot 11$ & $4 \cdot 9$ \\
Dimethylammonium & $0 \cdot 11$ & $8 \cdot 1$ \\
Trimethylammonium & $0 \cdot 14$ & $19 \cdot 9$ \\
Trimethylsulphonium & ND & $1 \cdot 4$ \\
Formaldehyde & ND & $2 \cdot 5$ \\
Formate & $0 \cdot 04$ & $7 \cdot 4$ \\
Acetate & $0 \cdot 12$ & ND \\
\hline
\end{tabular}

ND, Not determined. for a number of these compounds, supplied at an initial concentration of $15 \mathrm{mM}$, are shown in Table 1 . Formaldehyde was a toxic substrate, and while growth occurred on this compound at the concentration supplied, the yield observed may not reflect the true potential of the organism. Strain M2 also grew aerobically on ethanesulphonic acid, isethionate, serine, alanine, propionate, glycerol, lactate, pyruvate, succinate, glutamate, fructose, glucose, sucrose and thioacetamide. It grew weakly on nitromethane, cysteate, and propane-, butane- and pentanesulphonic acids. It did not grow on methane, hydrogen/carbon dioxide, methanephosphonate, DMS, dimethyl disulphide, carbon disulphide, methyl-MSA, monomethyl sulphate, taurine, thiosulphate, acetamide, ethanol, glycine, citrate or benzenesulphonate. Anaerobic growth was not observed under any condition tested.

\section{Growth of strain M2 in batch culture on MSA}

In batch culture without $\mathrm{pH}$ control, strain M2 grew aerobically on MSA $(10-40 \mathrm{mM})$ with a doubling time of 7-8 h. In a $750 \mathrm{ml}$ stirred and aerated culture on $15 \mathrm{mM}$ MSA the maximum specific growth rate $\left(\mu_{\max }\right)$ was about $0 \cdot 1 \mathrm{~h}^{-1}$, which was maintained while culture $\mathrm{pH}$ decreased progressively from the initial $\mathrm{pH} 7.0$ to $\mathrm{pH} 5.4$. Growth did not occur below pH 5.0 although the culture continued to produce acid to $\mathrm{pH} 4.5$ following cessation of growth. Low concentrations of formate (up to $1 \mathrm{mM}$ ) and sulphite were detected during growth. Yields of 8-14 g dry wt $\mathrm{mol}^{-1}$ were observed in batch cultures.

When strain M2 was grown on $\left[{ }^{14} \mathrm{C}\right] \mathrm{MSA}$, incorporation of ${ }^{14} \mathrm{C}$ and increase in biomass paralleled each other in rate, as did decrease in dissolved ${ }^{14} \mathrm{C}$ in the culture medium supernate. ${ }^{14} \mathrm{C}$ incorporation ceased when growth ceased and the ratio of ${ }^{14} \mathrm{C}$ from MSA assimilated relative to that lost as $\mathrm{CO}_{2}$ was about $1: 3$. At least $70 \%$ of the cell-carbon was indicated to arise from MSA in these experiments. In similar experiments in which strain M2 was grown on MSA (or monomethylammonium) in batch culture in sealed flasks with ${ }^{14} \mathrm{CO}_{2}$, only $10-18 \%$ of cellcarbon was derived from $\mathrm{CO}_{2}$.

\section{Growth of strain M2 in chemostat culture on MSA}

Steady-state biomass production of strain M2 in MSAlimited chemostat culture at $\mathrm{pH} 6.6$ was a function of dilution rate. Observed yields increased from $7 \cdot 0 \mathrm{~g} \mathrm{dry}$ wt (mol MSA) $)^{-1}$ at $D=0.04 \mathrm{~h}^{-1}$ to $14.6 \mathrm{~g} \mathrm{~mol}^{-1}$ at $0.09 \mathrm{~h}^{-1}$. From plots of $1 / Y \times 1 / D$ and of $q \times D$ [where $q=$ specific rate of substrate consumption, mmol MSA $(\mathrm{g} \text { dry wt })^{-1}$ ] for steady states at 10 different values of $D$ between 0.04 and $0.09 \mathrm{~h}^{-1}$, a maximum growth yield $\left(Y_{\max }\right)$ of about $19.0 \mathrm{~g} \mathrm{~mol}^{-1}$ and a maintenance coefficient of $3.4 \mathrm{mmol}$ MSA (g dry wt h) $)^{-1}$ were calculated. Biomass production at constant dilution rate was proportional to the MSA concentration provided. Thus at $D=0.04-0.05 \mathrm{~h}^{-1}$, yield was constant at $7 \cdot 1 \pm 0 \cdot 2 \mathrm{~g} \mathrm{~mol}^{-1}$ for input concentrations of 10,16 and $25 \mathrm{mM}$ MSA. Similarly at $D=0.065 \mathrm{~h}^{-1}$, yield was $9 \cdot 9 \pm 0 \cdot 2$ with either 16 or $30 \mathrm{mM}$ MSA. The maximum specific growth rate $\left(\mu_{\max }\right)$ was estimated from 
washout kinetics to be close to $0 \cdot 1 \mathrm{~h}^{-1}$ : when a culture in steady state on $30 \mathrm{mM}$ MSA at $D=0.075 \mathrm{~h}^{-1}$ was switched to a dilution rate of $0 \cdot 1 \mathrm{~h}^{-1}$, biomass concentration declined exponentially from $240 \mathrm{mg}$ dry wt $\mathrm{l}^{-1}$ on imposition of the higher $D$, to $156 \mathrm{mg} \mathrm{l}^{-1}$ after $100 \mathrm{~h}$. Apparent $\mu_{\max }$ in washout experiments was dependent on the previous culture growth rate: switching a culture in steady state at $D=0.05 \mathrm{~h}^{-1}$ to $D=0.11 \mathrm{~h}^{-1}$ resulted in biomass declining by $40 \%$ in $9 \mathrm{~h}$ and indicated a $\mu_{\max }$ of only $0.074 \mathrm{~h}^{-1}$.

Methanol, formaldehyde or formate were not detectable in steady-state cultures. Sulphate was produced from MSA but sulphite was not detected in cultures, and the consumption of $\mathrm{NaOH}$ to maintain constant $\mathrm{pH}$ was consistent with the production of sulphuric acid:

$$
\mathrm{CH}_{3} \mathrm{SO}_{3}^{-}+\mathrm{H}^{+}+2 \mathrm{O}_{2}=\mathrm{CO}_{2}+\mathrm{H}_{2} \mathrm{O}+\mathrm{SO}_{4}^{2-}+2 \mathrm{H}^{+}
$$

\section{Substrate oxidation spectrum of strain $\mathrm{M} 2$ and stoichiometry of oxidation of MSA and other $C_{q}$ substrates}

Earlier studies showed an MSA: oxygen stoichiometry of $1 \cdot 0: 1 \cdot 5$ rather than the $1 \cdot 0: 2 \cdot 0$ required by the equation for the complete oxidation of MSA. This incomplete oxidation was previously attributed to the accumulation of formate (Baker et al., 1991). We have now found that repeated washing of MSA-grown cells (5-6 times) in relatively large volumes of Tris $/ \mathrm{HCl}, \mathrm{pH} 7 \cdot 0$, produces cell suspensions that effect the complete oxidation of MSA and other $C_{1}$ substrates, including formate. The explanation of this finding is not known. Sulphite was not oxidized in the presence of strain M2 at a rate significantly greater than its autooxidation rate.

The oxidation of carbon compounds by washed cell suspensions of MSA-grown strain M2 was assessed using an oxygen electrode cell, and the rates of oxidation relative to MSA compared (Table 2). Relatively few compounds were oxidized and the ability to oxidize alkane sulphonates decreased with increase in chain length, with no oxidation at $\mathrm{C}_{4}$ and above by bacteria not previously exposed to these compounds. MSA-grown cells were capable of oxidizing amino-MSA and monomethyl sulphate, as well as formate and methanol, but primary alcohols of $>\mathrm{C}_{2}$ were not oxidized. MSA-grown organisms also did not oxidize methane, formamide, ethylene, mono-, di- or trimethylammonium, trimethylsulphonium, acetate, pyruvate, glucose or thiosulphate. While MSA was oxidized only by MSA-grown strain M2, methanol, formaldehyde and formate were all oxidized by cells grown on MSA, methanol, formaldehyde, formate or methylammonium, but not after growth on pyruvate. Methylammonium was oxidized only by cells grown on methylammonium, suggesting that the metabolism of this compound uses a different oxidation pathway from that of MSA. MSA oxidation only after growth on MSA suggested that a specific MSA-inducible oxygenase or other unique enzyme might be present in strain M2.

Strain M2, previously grown on MSA, exhibited $V_{\max }$ values for MSA, methanol and formaldehyde of 229,355
Table 2. Substrate oxidation spectrum of strain $M 2$ previously grown on MSA

\begin{tabular}{|lr|}
\hline Substrate (1.7 mM) & $\begin{array}{c}\text { Relative } \\
\text { oxidation rate* }\end{array}$ \\
\hline MSA & 100 \\
Amino-MSA & 86 \\
Ethanesulphonate & 36 \\
Propanesulphonate & 8 \\
Butanesulphonate & 0 \\
Pentanesulphonate & 0 \\
Ethane 1,2-disulphonate & 5 \\
Methanephosphonate & 0 \\
Monomethyl sulphate & 28 \\
Dichloromethane & 24 \\
Isethionate & 11 \\
Cysteate & 0 \\
Taurine & 0 \\
Methanol & 114 \\
Ethanol & 41 \\
Formate & 14 \\
\hline
\end{tabular}

$* 100 \%$ was $28 \cdot 4 \mathrm{nmol}$ oxygen $\min ^{-1}(\mathrm{mg} \text { dry wt cells })^{-1}$.

Table 3. Stoichiometry of oxidation of MSA and other $\mathrm{C}_{1}$ substrates

\begin{tabular}{|lcc|}
\hline Substrate & $\begin{array}{c}\text { Oxygen:substrate } \\
\text { stoichiometry* }\end{array}$ & $\begin{array}{c}\text { Apparent } \boldsymbol{K}_{\mathrm{m}} \\
\text { for } \mathbf{C}_{\mathbf{1}} \text { substrate } \\
(\boldsymbol{\mu} \mathbf{M})\end{array}$ \\
\hline MSA & $1.96(14)$ & 20 \\
Methanol & $1.43(6)$ & 110 \\
Formaldehyde & $0.97(4)$ & 66 \\
Formate & $0.48(8)$ & 42 \\
Monomethyl & $1.43(5)$ & 30 \\
sulphate & & \\
\hline
\end{tabular}

* Numbers in parenthesis indicate number of determinations.

and $198 \mathrm{nmol} \mathrm{O}_{2} \mathrm{~min}^{-1} \quad\left(\mathrm{mg} \mathrm{dry} \mathrm{wt}^{-1}\right)$, respectively. $V_{\max }$ values for formaldehyde were 150, 302, 216 and 138 for strain M2 grown respectively on methanol, formaldehyde, formate and methylammonium. Methanol was oxidized over a wide range of concentrations without evidence of marked toxicity. Oxidation rates $\left[\mathrm{nmol} \mathrm{O}_{2}\right.$ $\min ^{-1}$ (mg dry wt) ${ }^{-1}$ ] were $122-153$ between 0.3 and $130 \mathrm{mM}$ (eight values) and 135, 137 and 126 at 260, 530 and $820 \mathrm{mM}$.

Oxygen:substrate stoichiometries were determined for the principal $C_{1}$ substrates used by MSA-grown strain M2 (Table 3). These are indicative of the complete oxidation of substrates to carbon dioxide. Interestingly, monomethyl sulphate, which does not serve as a growth substrate for strain M2, was oxidized by strain M2, with a 
Table 4. Enzymes of $C_{1}$ metabolism in strain $M 2$

\begin{tabular}{|c|c|c|c|c|c|c|}
\hline \multirow[t]{2}{*}{ Growth substrate } & \multicolumn{2}{|c|}{$\begin{array}{c}\text { Hydroxypyruvate } \\
\text { reductase }\end{array}$} & \multicolumn{2}{|c|}{$\begin{array}{c}\text { Methanol } \\
\text { dehydrogenase }\end{array}$} & \multicolumn{2}{|c|}{$\begin{array}{c}\text { Formate } \\
\text { dehydrogenase }\end{array}$} \\
\hline & $K_{\mathrm{m}}(\mu \mathbf{M})$ & $V_{\max } *$ & $K_{\mathrm{m}}(\mu \mathrm{M})$ & $V_{\max } \dagger$ & $K_{\mathrm{m}}(\mu \mathrm{M})$ & $V_{\max } \ddagger$ \\
\hline MSA & $4 \cdot 4$ & 1120 & $0 \cdot 243$ & 115 & 3.53 & 47 \\
\hline Methanol & $4 \cdot 04$ & 1230 & $0 \cdot 221$ & 384 & $3 \cdot 15$ & 135 \\
\hline Formaldehyde & $4 \cdot 57$ & 978 & $0 \cdot 189$ & 104 & ND & ND \\
\hline Formate & $4 \cdot 14$ & 898 & $0 \cdot 183$ & 97 & 0.54 & 53 \\
\hline Methylammonium & $3 \cdot 82$ & 1010 & $0 \cdot 124$ & 104 & 1.57 & 75 \\
\hline
\end{tabular}

ND, Present, but not determined.

${ }^{*}, \dagger, \ddagger V_{\text {max }}$ values: ${ }^{*}$ nmol NADPH $\min ^{-1} \mathrm{mg}_{\text {protein }}{ }^{-1} ; \nmid$ nmol DCPIP $\min ^{-1} \mathrm{mg}$ protein ${ }^{-1} ; \ddagger \mathrm{nmol}$ NAD $\min ^{-1} \mathrm{mg}$ protein ${ }^{-1}$.

substrate: oxygen stoichiometry of $1: 1 \cdot 43$, which is in contrast to the partial oxidation with a $1: 1$ stoichiometry observed by Davies et al. (1990) with Agrobacterium sp. M3C.

\section{Enzyme activities in cell-free extracts of MSA-grown strain $\mathbf{M 2}$}

The presence of a methanesulphonate monooxygenase (MSMO) was indicated by the stimulation of NADH oxidation by cell-free extracts on the addition of MSA. A crude extract MSA-dependent specific activity of $59 \mathrm{nmol}$ NADH min $^{-1}$ (mg protein) ${ }^{-1}$ was observed. This activity was specifically induced by growth on MSA and was absent from methanol-grown cells. An NADH:MSA stoichiometry of 1:1 was observed in the cell-free MSMO assay. The purification and properties of this monooxygenase system will be described elsewhere ( $\mathrm{J}$. Trickett, T. Higgins \& J. C. Murrell, unpublished work).

MSA-grown strain M2 rapidly oxidized methanol and the presence of a pyrroloquinoline quinone (PQQ)-linked methanol dehydrogenase (MDH) typical of Gram-negative methylotrophs was confirmed by: (i) assaying the enzyme (Table 4); (ii) Western blotting cell-free extracts of strain M2 grown on various $\mathrm{C}_{1}$ compounds and probing with antibody to MDH from Methylobacterium extorquens AM1; and (iii) probing chromosomal DNA of strain M2 with a DNA probe encoding the structural gene for the large subunit of $\mathrm{MDH}(\operatorname{mox} F)$ from $M$. extorquens AM1. MDH activity was present in MSA-, methanol-, formaldehyde-, methylammonium- and formate-grown cells (Table 4). The large subunit of MDH was identified as a polypeptide of around $60 \mathrm{kDa}$ in MSA-, methanol-, and formate-grown cells by means of Western blotting experiments (data not shown). MDH activity, and the $60 \mathrm{kDa}$ polypeptide, were absent from pyruvate-grown cells. Southern blotting revealed the presence in strain M2 of several chromosomal DNA fragments with a high degree of homology (hybridization conditions allowing for approximately $15 \%$ base pair mismatch) to the $\operatorname{moxF}$ gene of $M$. extorquens AM1.
High activities of hydroxypyruvate reductase were found in cell extracts from cells grown on all $C_{1}$ substrates tested (Table 4), indicating the serine pathway to be the central assimilatory system for formaldehyde in strain M2.

Formate dehydrogenase activities in cell-free extracts were consistent with the dissimilation of formate to $\mathrm{CO}_{2}$ by an NAD-linked formate dehydrogenase (Table 4).

Hexulose phosphate synthase activity was not found in cell-free extracts prepared from organisms grown on any $\mathrm{C}_{1}$ compound. Control experiments with cell-free extracts of methane-grown Metbylococcus capsulatus (Bath) gave a positive hexulose phosphate synthase assay.

RubisCO activity was not detected in whole organisms of strain M2, previously grown on MSA or formate, using the CTAB- or Triton X-100-permeabilization methods. Control experiments using autotrophically-grown Thiobacillus versutus gave good RubisCO activities under the same conditions. Cell-free extracts of MSA- or formategrown strain M2 showed no cross-reactivity when Western-blotted and challenged with antisera to form I and II RubisCO from Rbodobacter sphaeroides or antiserum to Synechococcus RubisCO. Similarly, RubisCO gene probes from Anacystis (Quivey \& Tabita, 1984) and Rhodobacter sphaeroides (Gibson \& Tabita, 1987) did not hybridize to strain M2 chromosomal DNA after stringent washing procedures. No plasmids have been detected in strain M2 (P. De Marco \& J. C. Murrell, unpublished), excluding the possibility of a plasmid-borne RubisCO. Strain M2 is thus not able to synthesize this enzyme.

\section{DISCUSSION}

Strain M2 has been shown to be a facultative methylotroph with the unusual property of using MSA as sole carbon and energy source. Its relatively high $\mathrm{G}+\mathrm{C}$ content $(61 \mathrm{~mol} \%)$, the absence of RubisCO and hexulose phosphate synthase, but the presence of a high specific activity of NADPH-dependent hydroxypyruvate reductase, are all consistent with strain $\mathrm{M} 2$ being a typical serine pathway methylotroph. Other methylotrophs cannot, 
however, use MSA (Baker et al., 1991) and strain M2 is significantly different from Metbylobacterium, Metbylobacillus, Metbylopbilus and methylotrophic species of Pseudomonas. Until its wider taxonomic affinities have been evaluated further it is not possible to assign strain M2 to a genus. To this end we propose to determine the $16 \mathrm{~S}$ rRNA sequence for this organism, but this is not yet available.

Growth of strain M2 on MSA was neither chemolithoautotrophic (from sulphonate-sulphur oxidation) nor autotrophic, as energy could not be obtained from thiosulphate by the organism, and carbon dioxide fixation contributed only about $15 \%$ of cell-carbon during methylotrophic growth. The enzymological evidence presented is consistent with the serine pathway being the principal route for carbon assimilation during growth on any one of MSA, the methylammoniums, methanol, formaldehyde or formate. It is noteworthy that the growth yields in batch culture on MSA and methanol were similar (Table 1), and that these were comparable to the values of $12-14 \mathrm{~g} \mathrm{~mol}^{-1}$ seen with other serine pathway methylotrophs growing on methanol (Goldberg et al., 1976). Calculations by Harder et al. (1980) indicated a yield on methanol (by serine pathway methylotrophs) of at least $19.5 \mathrm{~g} \mathrm{~mol}^{-1}$ to be feasible (based on $50 \%$ energy conservation efficiency). The yields of strain M2 on MSA observed in the chemostat $\left(7 \cdot 0-14.6 \mathrm{~g} \mathrm{~mol}^{-1}\right)$, and the calculated $Y_{\max }$ of 19.0 are thus consistent with the theoretical limits. A useful comparison may be made with the yields of Hyphomicrobium EG, growing on dimethyl sulphoxide, as the oxidation of this compound may involve reactions (e.g. NADH-consuming oxygenations) akin to those in the metabolism of MSA. The Hyphomicrobium yield of $8.3 \mathrm{~g}$ dry wt (DMSO-methyl-unit) ${ }^{-1}$ (Suylen, 1988) falls in the range observed for strain M2 on MSA.

Strain M2 oxidized various $C_{1}$ compounds with substrate: oxygen stoichiometries consistent with complete oxidation according to the following equations:

$$
\begin{aligned}
\mathrm{CH}_{3} \mathrm{SO}_{3} \mathrm{H}+2 \mathrm{O}_{2} & =\mathrm{CO}_{2}+\mathrm{H}_{2} \mathrm{O}+\mathrm{H}_{2} \mathrm{SO}_{4} \\
\mathrm{CH}_{3} \mathrm{OH}+1 \cdot 5 \mathrm{O}_{2} & =\mathrm{CO}_{2}+2 \mathrm{H}_{2} \mathrm{O} \\
\mathrm{HCHO}+1 \cdot 0 \mathrm{O}_{2} & =\mathrm{CO}_{2}+\mathrm{H}_{2} \mathrm{O} \\
\mathrm{HCOOH}+0 \cdot 5 \mathrm{O}_{2} & =\mathrm{CO}_{2}+\mathrm{H}_{2} \mathrm{O} \\
\mathrm{CH}_{3} . \mathrm{O} . \mathrm{SO}_{3} \mathrm{H}+1 \cdot 5 \mathrm{O}_{2} & =\mathrm{CO}_{2}+\mathrm{H}_{2} \mathrm{SO}_{4}+\mathrm{H}_{2} \mathrm{O}
\end{aligned}
$$

There are several possibilities for the mechanism of oxidation of MSA by strain M2. The first could involve hydrolysis of MSA to produce methane and sulphate in a reaction analogous to the $\mathrm{C}-\mathrm{P}$ cleavage of methanephosphonate seen in Pseudomonas testosteroni (Daughton et al., 1979). This is unlikely, since the organism does not grow on or oxidize methane. An alternative could be the hydrolysis of MSA to methanol and sulphurous acid:

$$
\mathrm{CH}_{3} \mathrm{SO}_{3} \mathrm{H}+\mathrm{H}_{2} \mathrm{O}=\mathrm{CH}_{3} \mathrm{OH}+\mathrm{H}_{2} \mathrm{SO}_{3}
$$

The methanol produced would then be oxidized to formaldehyde by MDH. This mechanism has been discounted, since cyclopropanol, a specific inhibitor of PQQ-linked $\mathrm{MDH}$, allows the complete oxidation of

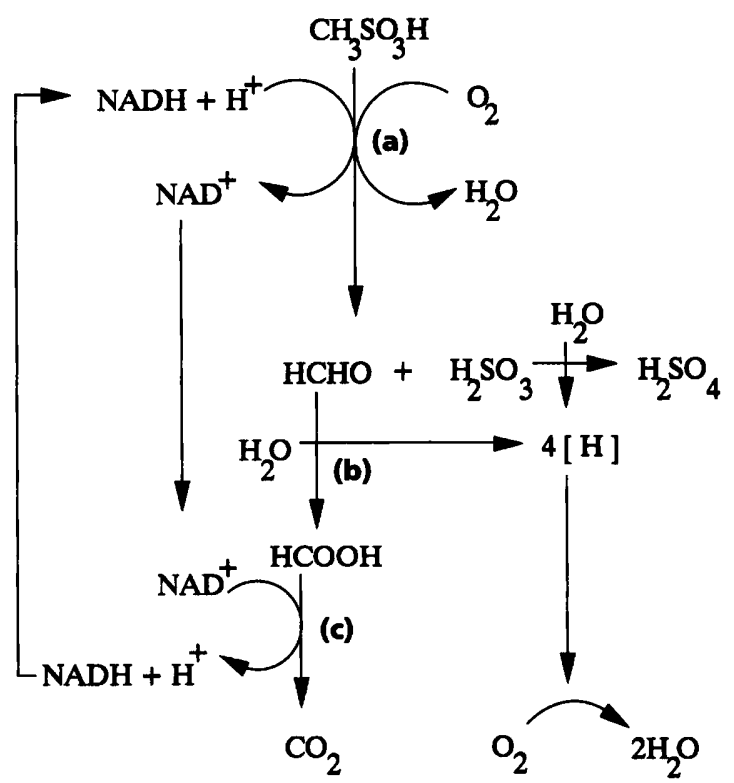

Fig. 1. Proposed mechanism for the metabolism of MSA by strain M2. Key reactions are (a) methanesulphonate monooxygenase (MSMO), producing formaldehyde and sulphite from MSA; (b) formaldehyde dehydrogenase; (c) formate dehydrogenase.

MSA by MSA-grown cells of strain M2, but inhibits methanol oxidation in the same cells (J. Trickett \& J. C. Murrell, unpublished observations). We have also recently isolated mutants of strain M2 that fail to grow on methanol but still grow on MSA (M. Davey \& J. C. Murrell, unpublished). Another possibility could be the formation of methyltetrahydrofolate and sulphate from MSA, analogous to Pseudomonas MS growing on trimethylsulphonium chloride (Kung \& Wagner, 1970; Wagner et al., 1967). This compound was, however, only a poor growth substrate for strain M2 and was not oxidized by MSA-grown cells.

The presence of the NADH-dependent MSA-specific monooxygenase suggests that MSA degradation is initiated by monooxygenase cleavage of the MSA to produce formaldehyde (and sulphite), according to the following stoichiometry:

$\mathrm{CH}_{3} \mathrm{SO}_{3} \mathrm{H}+\mathrm{O}_{2}+\mathrm{NADH}+\mathrm{H}^{+}=\mathrm{HCHO}+\mathrm{NAD}^{+}+\mathrm{H}_{2} \mathrm{SO}_{3}+\mathrm{H}_{2} \mathrm{O}$

Subsequent oxidation of formaldehyde via formate to carbon dioxide and water would yield energy and reducing power for growth (and NADH for the monoxygenase), and growth would depend on formaldehyde assimilation by a conventional serine pathway. The mechanism proposed for the metabolism of MSA by strain M2 is outlined in Fig. 1.

Our findings broaden the range of $\mathrm{C}_{1}$ substrates known to be used by methylotrophs and provide evidence of a new monooxygenase system, specific for MSA. The demonstration of MSA utilization and complete degradation 
by strain M2 is of particular importance because it provides direct evidence of a microbiological link in the biogeochemical cycling of sulphur, enabling reoxidation in terrestrial and aquatic environments of MSA generated in the atmosphere from DMS. MSA is now recognized as a major intermediate of the air/sea/atmosphere exchange of sulphur and it seems likely that strain M2 is but one example of what may be an abundance of as yet uncharacterized MSA-degrading organisms.

\section{ACKNOWLEDGEMENTS}

We thank the SERC for a research studentship to Simon Baker, and the NERC for financial support (Grant no. GR3/8242).

\section{REFERENCES}

Andreae, M. O. (1986). The ocean as a source of atmospheric sulfur compounds. In The Role of Air-Sea Exchange in Geocbemical Cycling, pp. 331-362. Edited by P. Buat-Ménard. New York: Reidel.

Baker, S. C., Kelly, D. P. \& Murrell, J. C. (1991). Microbial degradation of methanesulphonic acid: a missing link in the biogeochemical sulphur cycle. Nature 350, 627-628.

Berresheim, H., Andreae, M. O., Ayers, G. P., Gillett, R. W., Merill, J. T., Davis, V. J. \& Chameides, W. L. (1990). Airborne measurements of dimethyl sulfide, sulfur dioxide, and aerosol ions over the Southern Ocean south of Australia. J Atmos Chem 10, 341-370.

Biedlingmaier, S. \& Schmidt, A. (1983). Alkylsulphonic acids and some S-containing detergents as sulfur sources for growth of Cblorella fusca. Arch Microbiol 136, 124-139.

Bradford, M. M. (1976). A rapid and sensitive method for the quantitation of microgram quantities of protein using the principle of protein-dye binding. Anal Biocbem 72, 248-254.

Cook, A. M. \& Hütter, R. (1982). Ametryne and prometryne as sulphur sources for bacteria. Appl Environ Microbiol 43, 781-786.

Dacey, J. W. H., King, G. M. \& Wakeham, S. G. (1987). Factors controlling emission of dimethyl sulphide from salt marshes. Nature 330, 643-645.

Daughton, C. G., Cook, A. M. \& Alexander, M. (1979). Biodegradation of phosphate toxicants yields methane or ethane on cleavage of the C-P bond. FEMS Microbiol Lett 5, 91-93.

Davies, I., White, G. F. \& Payne, W. J. (1990). Oxygen-dependent desulphation of monomethyl sulphate by Agrobacterium sp. M3C. Biodegradation 1, 229-241.

Day, D. J. \& Anthony, C. (1990). Methanol dehydrogenase from Metbylobacterium extorquens AM1. Methods Engymol 188, 210-215.

Ferek, R. J., Chatfield, R. B. \& Andreae, M. O. (1986). Vertical distribution of dimethyl sulphide in the marine atmosphere. Nature 320, 514-516.

Fredericq, E., Oth, A. \& Fontaine, F. (1961). The ultraviolet spectrum of deoxyribonucleic acids and their constituents. $J \mathrm{Mol}$ Biol 3, 11-17.

Gerhardt, P. (1981). Diluents and biomass measurements. In Manual of Methods for General Bacteriology, pp. 504-507. Edited by P. Gerhardt and others. Washington, DC: American Society for Microbiology.

Gibson, J. L. \& Tabita, F. R. (1987). Organisation of phosphoribulokinase and ribulose bisphosphate carboxylase/oxygenase genes in Rhodopseudomonas (Rhodobacter) sphaeroides. J Bacteriol 169, 3685-3690.

Goldberg, I., Rock, J. S., Ben-Bassett, A. \& Mateles, R. J. (1976).
Bacterial yields on methanol, methylamine, formaldehyde, and formate. Biotechnol Bioeng 18, 1657-1668.

Grosjean, D. \& Lewis, R. (1982). Atmospheric photooxidation of methyl sulphide. Geophys Res Lett 9, 1203-1206.

Harder, W., van Dijken, J. P. \& Roels, J. A. (1980). Utilization of energy in methylotrophs. In Microbial Growth on $C_{1}$ Compounds, pp. 258-269. Edited by H. Dalton. London: Heyden.

Hatakeyama, S., Okunda, M. \& Akinoto, H. (1982). Formation of sulphur dioxide and methanesulphonic acid in the photooxidation of dimethyl sulphide in the air. Geophys Res Lett 9, 583-586.

Jensen, N. R., Hjorth, J., Lohse, C., Skov, H. \& Restelli, G. (1991). Products and mechanisms of the reaction between $\mathrm{NO}_{3}$ and dimethylsulphide in air. Atmos Environ 25A, 1897-1904.

Jensen, N. R., Hjorth, J., Lohse, C., Skov, H. \& Restelli, G. (1992). Products and mechanisms of the gas phase reactions of $\mathrm{NO}_{3}$ with $\mathrm{CH}_{3} \mathrm{SCH}_{3}, \mathrm{CD}_{3} \mathrm{SCD}_{3}, \mathrm{CH}_{3} \mathrm{SH}$ and $\mathrm{CH}_{3} \mathrm{SSCH}_{3} . J$ Atmos Chem 14, 95-108.

Johnston, J. B., Murray, K. \& Cain, R. B. (1975). Microbial metabolism of aryl sulphonates. A re-assessment of colorimetric methods for the determination of sulphite and their use in measuring desulphonation of aryl and alkylbenzene sulphonates. Antonie Leeuwenhoek 41, 493-511.

Jollie, D. R. \& Lipscombe, J. D. (1990). Formate dehydrogenase from Metbylosinus trichosporium OB3b. Metbods Enzymol 188, 331-34.

Kelly, D. P. \& Smith, N. A. (1990). Organic sulphur compounds in the environment. Biogeochemistry, microbiology and ecological aspects. Adv Microb Ecol 11, 345-385.

Kelly, D. P. \& Wood, A. P. (1984). Potential for methylotrophic autotrophy in Thiobacillus versutus (Thiobacillus A2). In Microbial Growth on $C_{1}$ Compounds, pp. 324-329. Edited by R. L. Crawford \& R. S. Hanson. Washington, DC: American Society for Microbiology.

Kelly, D. P., Malin, G. \& Wood, A. P. (1993). Microbial transformations and biogeochemical cycling of one-carbon substrates containing sulphur, nitrogen or halogens. In Microbial Growth on $C_{1}$ Compounds, pp. 47-63. Edited by J. C. Murrell \& D. P. Kelly. Andover: Intercept.

Kiene, R. P. (1993). Microbial sources and sinks for methylated sulphur compounds in the marine environment. In Microbial Growth on $C_{1}$ Compounds, pp. 15-33. Edited by J. C. Murrell \& D. P. Kelly. Andover: Intercept.

Krauss, F. \& Schmidt, A. (1987). Sulphur sources for the growth of Cblorella fusca and their influence on key enzymes of sulphur metabolism. J Gen Microbiol 133, 1209-1219.

Kung, H.-F. \& Wagner, C. (1970). Oxidation of $C_{1}$ compounds by Pseudomonas sp. MS. Biochem J. 116, 257-265.

Laemmli, U. K. (1970). Cleavage of structural proteins during the assembly of the head of bacteriophage T4. Nature 227, 680-685.

Lang, E. \& Lang, H. (1972). Spezifische Farbreaktionen zum direkten Nachweis der Ameisensäure. Zentralbl Chem 260, 8-10.

Leadbeater, L., Siebert, K., Schobert, P. \& Bowien, B. (1982). Relationship between activities and protein levels of ribulose bisphosphate carboxylase and phosphoribulokinase in Alcaligenes eutrophus. FEMS Microbiol Lett 14, 263-266.

Maniatis, T., Fritsch, E. F. \& Sambrook, J. (1982). Molecular Cloning: a Laboratory Manual. Cold Spring Harbor, NY: Cold Spring Harbor Laboratory.

Nash, T. (1953). The colorimetric estimation of formaldehyde by means of the Hantzsch reaction. Biochem $J$ 55, 416-421.

Oakley, C. J. \& Murrell, J. C. (1988). nif $\mathrm{H}$ genes in the obligate methane oxidising bacteria. FEMS Microbiol Lett 49, 53-57. 
Owens, J. D. \& Keddie, R. M. (1969). The nitrogen nutrition of soil and herbage bacteria. J. Appl Bacteriol 32, 338-349.

Quivey, R. G. \& Tabita, F. R. (1984). Cloning and expression in Escherichia coli of the form II ribulose 1,5-bisphosphate carboxylase/ oxygenase from Rhodopseudomonas sphaeroides. Gene 31, 91-101.

Saigne, C. \& Legrand, N. (1987). Measurements of methanesulphonic acid in Antarctic ice. Nature 330, 240-242.

Suylen, G. M. H. (1988). Microbial metabolism of dimetbyl sulphide and related compounds. Proefschrift (Doctoral thesis), Technical University, Delft.

Towbin, H., Staehelin, T. \& Gordon, J. (1979). Electrophoretic transfer of proteins from polyacrylamide gel to nitrocellulose sheets : procedure and some applications. Proc Natl Acad Sci US.A 76, 4350-4354.

Tuovinen, O. H. \& Kelly, D. P. (1973). Studies on the growth of Thiobacillus ferrooxidans I. Use of membrane filters and ferrous iron agar to determine viable numbers, and comparison of ${ }^{14} \mathrm{CO}_{2}$ fixation and iron oxidation as measures of growth. Arch Mikrobiol 88, 285-298.

Uria-Nickelsen, M. R., Leadbetter, E. R. \& Godchaux, W., III (1993).
Sulphonate utilisation by enteric bacteria. J Gen Microbiol 139, 203-208.

Wagner, C., Lusty, S. M., Kung, H.-F. \& Rogers, N. L. (1967). Preparation and properties of trimethylsulfonium-tetrahydrofolate methyltransferase. J Biol Chem 242, 1287-1293.

Watts, S. F., Brimblecombe, P. \& Watson, A. J. (1990). Methanesulphonic acid, dimethyl sulphoxide and dimethyl sulphone in aerosol. Atmos Environ 24A, 253-259.

Wood, A. P. \& Kelly, D. P. (1989). Isolation and physiological characterisation of Thiobacillus thyasiris sp. nov., a novel marine facultative autotroph and the putative symbiont of Tbyasira flexuosa. Arch Microbiol 152, 160-166.

Yin, F., Grosjean, D., Flagan, R. C. \& Seinfled, J. H. (1990). Photooxidation of dimethyl sulphide and dimethyl disulphide. II. Mechanism evaluation. $J$ Atmos Chem 11, 309-399.

de Zwart, J. M. M. \& Kuenen, J. G. (1992). $C_{1}$-cycle of sulfur compounds. Biodegradation 3, 37-59.

Received 8 December 1993; accepted 1 February 1994. 